\title{
International Tax Reform: Hearing Before the S. Comm. on Fin., 115th Cong., Oct. 3, 2017 (Statement of Itai Grinberg)
}

Itai Grinberg

Georgetown University Law Center, itai.grinberg@law.georgetown.edu

This paper can be downloaded free of charge from:

http://scholarship.law.georgetown.edu/cong/121 


\title{
TESTIMONY OF ITAI GRINBERG Professor of Law, Georgetown University LaW Center
}

\author{
Before the Senate Finance Committee \\ HEARING ON INTERNATIONAL TAX REFORM
}

October 3, 2017

Chairman Hatch, Ranking Member Wyden, and Members of the Committee, it is an honor to participate in these hearings on international tax reform. I am a professor of law at the Georgetown University Law Center. I served in the Office of International Tax Counsel in both the George W. Bush and Obama administrations. Before joining the Treasury Department I practiced international tax law at Skadden Arps in Washington, and in 2005 I served as counsel to the bipartisan President's Advisory Panel on Federal Tax Reform.

The interconnectedness of today's global economy and the mobility of capital, intellectual property, and high-skilled labor make all attempts to impose high income tax rates on multinational corporations (MNCs) counterproductive. The global market for corporate control combined with the home-country bias for high-quality headquarters and R\&D jobs means that lagging in this area will be increasingly costly in terms of employment and opportunity, especially for younger generations of Americans.

Our singularly high corporate tax rate and worldwide system are severely out of line with international norms. The United States' statutory corporate income tax rate is the highest in the Organisation for Economic Cooperation and Development (OECD), and our effective corporate tax rate is also high. ${ }^{1}$ Every other 67 country and 29 of the other 34 OECD member countries allow their resident companies to repatriate active foreign business income to their home country without paying a significant additional domestic tax. This system of taxation is usually referred to as "dividend exemption" or a "territorial tax system."

There is now a widespread consensus that the United States needs to reform its aberrant worldwide corporate tax system and that such reform should involve lowering the tax rate and adopting a territorial tax system. Other countries have been taking these steps for years, while also increasing their reliance on consumption taxes and decreasing their reliance on corporate income taxes. Indeed, since the 1986 Act, other OECD countries have reduced their collective average corporate tax rate by more than nineteen percentage points. ${ }^{2}$

\footnotetext{
${ }^{1}$ For instance, Philip Bazel and Jack Mintz find that the U.S. has a marginal effective tax rate on corporate investment that is more than 15 percentage points higher than the OECD average and represents the 3rd-highest marginal effective tax rate in the OECD, after only France and Japan. Philip Bazel \& Jack Mintz, 2015 TaxCompetitiveness Report: Canada is Losing its Attractiveness, 9:37 SPP Research Papers (Nov. 2016), https://www.policyschool.ca/wp-content/uploads/2016/12/Tax-Competitiveness-Bazel-Mintz.pdf.

${ }^{2}$ See U.S. Tax Code: Love It, Leave It, or Reform It: Hearing Before the Sen. Comm. on Finance, 113 th Cong. 2 (2014) (Statement of Peter R. Merrill, Director of the National Economics and Statistics Group at PricewaterhouseCoopers LLP), https://www.finance.senate.gov/download/merrill.
} 
The Committee has examined these issues since at least 2010, and many hearings have focused on these matters. ${ }^{3}$ Substantially reducing the corporate income tax rate and moving to a territorial system are important steps the United States should take. But these steps are not enough.

Rather than restate the rationale for lowering the corporate rate and moving to a territorial system, which has been eloquently explained by many witnesses at earlier Committee hearings over the course of this decade, ${ }^{4}$ my testimony will focus on one significant issue within international tax reform that has received much less attention in prior hearings and from U.S. policymakers generally. The issue involves rectifying the relative advantages that U.S. law gives to foreign MNCs investing in the United States that make foreign status more attractive than U.S. status.

The current U.S. international tax regime makes foreign ownership of almost any asset or business more attractive than U.S. ownership from a tax perspective, thereby creating tax-driven incentives for foreign takeovers of U.S. firms and foreign acquisition of business units previously owned by U.S. MNCs. It also creates substantial financial pressures that encourage U.S. MNCs to "invert" (move their headquarters abroad), produce abroad for the U.S. market, and shift business income to low-tax jurisdictions abroad. Finally, given a global business environment in which corporate tax residence is increasingly elective, new firms have significant incentives to incorporate their parent firm outside the United States at the moment of formation. The worldwide system and high rate that creates these tax incentives is not in America's interest.

As is the case with our worldwide system and high rate, in failing to address the taxation of foreign direct investment into the United States (known as "inbound taxation"), the U.S. is a global outlier. In the rest of the world, governments have been focusing their policy efforts in the last decade almost exclusively on inbound taxpayers that minimize their income in local jurisdictions. Especially given this global reality, U.S. corporate tax reform must also focus on how the U.S. tax system disfavors U.S. MNCs relative to the treatment of inbound taxpayers.

In the past, the tax disadvantages of U.S. status were balanced against the non-tax advantages of being a U.S.-resident firm. However, foreign firms are increasingly able to replicate the non-tax benefits of being a U.S. tax-resident MNC. The globalization of securities markets has made it relatively easy to raise funds in foreign capital markets and to access U.S. capital markets as a foreign firm. The globalization of best practices in corporate governance has made U.S.

\footnotetext{
${ }^{3}$ Indeed, at the Committee's July 2017 hearing, John Talisman, who served as Assistant Secretary of the Treasury for Tax Policy in the Clinton administration, pointed out that he had testified at a hearing in front of the Committee in 2011 entitled "How Did We Get Here" and joked that he wondered why the July 2017 hearing wasn't titled "Why are We Still Here?" Comprehensive Tax Reform: Prospects and Challenges; Hearing Before the Senate Comm. on Finance, 115th Cong. 1 (2017) (Statement of John Talisman). Those of us who have been following these matters for years appreciated the humor, but I feel confident the country would appreciate the benefits of corporate tax reform a great deal more.

${ }^{4}$ See, e.g., Comprehensive Tax Reform: Prospects and Challenges: Hearing Before the Senate Comm. on Finance, 115th Cong. (2017) (Statement of Pamela F. Olson), https://www.finance.senate.gov/imo/media/doc/Pamela\%20Olson\%20Testimony.pdf; The U.S. Tax Code: Love It, Leave It, or Reform It: Hearing Before the Senate Comm. on Finance, 113th Cong. 9 (2014) (Statement of Mihir A. Desai); Navigating Business Tax Reform: Hearing Before the Senate Comm. On Finance, $114^{\text {th }}$ Cong. 11 (2016) (Statement of James Hines).
} 
corporate governance rules less of a factor in firm valuations. ${ }^{5}$ As a result, the tax disadvantage increasingly outweighs the non-tax advantages of U.S. residency. ${ }^{6}$ In our globalized economy, the result over time is a long-term trend towards foreign-resident MNCs and away from U.S.resident MNCs. The inversion phenomenon is just one symptom of that trend. ${ }^{7}$ Since 2000, the number of U.S.-resident MNCs among the 500 largest public companies in the world as measured by Forbes has declined by over 25\%, from 202 in 2000 to 147 in 2016.

\section{The Role of U.S. and Foreign MNCs in the U.S. Economy}

Globally engaged MNCs, whether they be U.S. or foreign-parented firms, provide jobs for a large part of the American work force and higher wage employment than other parts of the American private sector. U.S.-headquartered MNCs employ 26.6 million workers in the United States. ${ }^{8}$ Majority-owned U.S. affiliates of foreign MNCs employ another 6.8 million workers in the United States. ${ }^{9}$ Together U.S. and foreign-headquartered MNCs represent more than $25 \%$ of total private sector payroll employment in the United States. ${ }^{10}$ Total compensation per American worker employed by both U.S. and foreign-headquartered MNCs averages about one-third more than the rest of the U.S. private sector.

There are various explanations for why MNCs generally offer better wages and jobs than most purely domestic firms. For instance, multinationals may require a higher-skilled labor force because of the technological requirements and competitive need to produce higher quality goods associated with competing globally. Given that MNCs require a higher-quality product, they may pay efficiency wages - as higher quality products require higher quality workers, MNCs pay more to induce more effort from workers.

U.S. MNCs, however, are more closely tied to the United States than their foreign competitors. The domestic affiliates of U.S. MNCs perform $84.3 \%$ of the worldwide research and

\footnotetext{
5 Julie A. Roin, Inversions, Related Party Expenditures, and Source Taxation: Changing the Paradigm for the Taxation of Foreign and Foreign-Owned Businesses, 2016 BYU L. REV. 1837, 1852 (Apr. 2017); see also DANIEL N. SHAVIRO, FIXING U.S. INTERNATIONAL TAXATION (2014).

${ }^{6}$ Indeed, corporations have also become increasingly "decentered" in recent years, such that corporate tax residence need not necessarily dictate the location of business functions. Mihir Desai, The Decentering of the Global Firm, 32 WORLD ECON. (SPECIAL ISSUE) 1271 (Sept. 2009). However, as discussed below, the BEPS project put a premium on shifting management and research and development jobs to the locations where a MNC wishes to be taxed.

${ }^{7}$ See, e.g., Eric Solomon, Corporate Inversions: A Symptom of Larger Tax System Problems, 67 TAX NOTES 1203 (Sept. 24, 2012).

${ }^{8}$ Sarah P. Scott, Activities of U.S. Multinational Enterprises in the United States: Preliminary Results From the 2014 Benchmark Survey, 96:12 Survey of Current Business, Dec. 2016, https://www.bea.gov/scb/pdf/2016/12\%20December/1216_activities_of_us_multinational_enterprises.pdf.

${ }^{9}$ Sarah Stutzman, Activities of U.S. Affiliates of Foreign Multinational Enterprises in 2015, 97:8 Survey of Current Business, Aug. 2017, https://www.bea.gov/scb/pdf/2017/08-August/0817-activities-of-us-affiliates-of-foreignmultinational-enterprises.pdf

${ }^{10}$ Moreover, both U.S. and foreign multinationals purchase trillions of dollars of intermediate inputs each year from other U.S. companies, helping sustain other private sector employment in America. Kevin B. Barefoot, U.S. Multinational Companies: Operations of U.S. Parents and Their Foreign Affiliates in 2010, 92:11 Survey of Current Business 51, 52, Nov. 2012, https://www.bea.gov/scb/pdf/2012/11\%20November/1112MNCs.pdf.
} 
development undertaken by U.S. MNCs. ${ }^{11}$ These domestic affiliates also represented more than two-thirds of worldwide U.S. MNC employment.

\section{The Importance of Encouraging MNCs to Remain American}

In order to maximize the opportunity for well-paid employment for future generations of Americans, we need to ensure that multinationals can be U.S.-headquartered and still compete effectively with their foreign MNC competitors. Expansion abroad by affiliates of U.S. multinationals tends to support their U.S.-parent jobs. Economic research shows that more affiliate investment and employment is generally associated with more investment and employment back in U.S. parents. For instance, Mihir Desai and James Hines find based on 1982-2004 U.S. Bureau of Economic Analysis data that on average, a 10\% increase in foreign subsidiary sales is associated with a $6.5 \%$ increase in U.S. exports. ${ }^{12}$ They also find that a $10 \%$ expansion of foreign employment by U.S. MNCs is associated with a 3.7 percent expansion of domestic employment by the same firms at the same time. As the Senate Finance Committee's bipartisan international tax working group report highlighted, the data suggests that for each dollar of additional wages paid in U.S. foreign affiliates, U.S. wages increase by $\$ 1.84 .{ }^{13}$ Relying on still other studies, Greg Mankiw and Phillip Swagel conclude that for U.S. MNCs, "success overseas leads to job gains in the United States." 14

No study reaches the same conclusion about foreign expansion by foreign MNCs. Indeed, the results of the studies described above regarding the effects of of U.S. MNC growth abroad would suggest that when foreign companies expand outside the United States, related headquarters investment and employment would tend to accrue in their home country. ${ }^{15}$ Importantly - this turns out to be the case even with formerly U.S.-tax resident corporations that have substantial presence in the United States but change their country of tax residency. Nirupama Rao has shown that former U.S. MNCs that undertake inversions subsequently develop higher shares of their employees and capital expenditures abroad after inversion, relative to similar firms that remain U.S. tax resident. ${ }^{16}$ In effect, the data suggests that a tax-motivated inversion may subsequently create other incentives to offshore more jobs, just like being a historically foreign-

\footnotetext{
${ }^{11}$ Barefoot, supra note 10 , at 54.

${ }^{12}$ Mihir Desai, C. Fritz Foley \& James R. Hines, Jr., Domestic Effects of the Foreign Activities of US Multinationals, AM. ECON. J.: ECON. POL'Y, no. 1 (Feb. 2009).

13 U.S. Sen. COMM. Fin., The International TAX Bipartisan TAX Working Group Report (2015), https://www.finance.senate.gov/imo/media/doc/The\%20International\%20Tax\%20Bipartisan\%20Tax\%20Working\% 20Group\%20Report.pdf.

${ }^{14}$ N. Gregory Mankiw \& Phillip Swagel, The Politics and Economics of Offshore Outsourcing (Nat'l Bureau of Econ. Research, Working Paper No. 12398, 2006).

${ }^{15}$ It is clear that policymakers in other major developed economies have this intuition. As with some other economic issues, U.S. data in this regard is often more robust than foreign data. Study of Japanese MNCs similarly shows that Japanese outbound investment is correlated with increased Japanese domestic employment. Mitsuyo Ando \& Fukunari Kimura, International Production/Distribution Networks and Domestic Operations in Terms of Employment and Corporate Organization: Microdata Analysis of Japanese Firms, REITI Discussion Paper Series 07-E-063 (2007).

${ }^{16}$ Nirupama Rao, Corporate Inversions and Economic Performance, 68 NAT'L TAX J. 1073 (2015). As Rao's paper highlights, the changes in hiring and investment resulting from inversion are not attributable to the onetime effects on the data due to the inclusion of the foreign acquiring firm's existing workforce and investments. Rather, foreign shares of employment and investment are systematically higher two and more years after inversion, relative to the first year after inversion.
} 
headquartered MNC exerts a kind of gravitational force that keeps a higher percentage of the best jobs in the firm outside the United States.

\section{$\underline{\text { Greenfield and Brownfield Foreign Direct Investment }}$}

Foreign investment into the United States is broadly categorized into two buckets by the U.S. Department of Commerce: the establishment of new U.S. businesses or the expansion of existing U.S. businesses (referred to as "greenfield investment"), and the acquisition of existing U.S. businesses ("brownfield investment"). Greenfield investment in the United States by foreign firms should unquestionably be welcomed by the United States. When a foreign MNC purchases a business unit from a U.S. MNC, or acquires a U.S. MNC, for the reason that the foreign MNC can use that business more productively, and therefore generate higher levels of output and employment from that business, we should also welcome that inbound investment.

Importantly, however, the data suggests that the vast majority of inbound foreign direct investment represents the transfer of ownership of businesses rather than greenfield investment. In 2016, expenditures by foreign direct investors made to acquire U.S. firms totaled $\$ 365.7$ billion, whereas expenditures by foreign direct investors to establish new U.S. businesses totaled $\$ 5.6$ billion and expenditures to expand existing foreign-owned U.S. businesses totaled \$2.2 billion. ${ }^{17}$ In other words, less than $3 \%$ of 2016 foreign direct investments were greenfield investments. The Department of Commerce Bureau of Economic Analysis data for earlier years in this century also shows that the vast majority of foreign direct investment consists of acquisitions of existing U.S. businesses rather than the establishment of new U.S. businesses or the expansion of existing U.S. businesses.

What drives foreign direct investor acquisitions is that the domestic business being acquired has greater financial value to a foreign firm than it does to the prior domestic owner. When that higher value is based on the ability of the foreign direct investor to make the domestic business more productive, the acquisition is likely to support American employment. In other cases, though - as shown in Senator Portman's Permanent Subcommittee on Investigations study entitled Impact of the U.S. Tax Code on the Market for Corporate Control and Jobs, "foreign acquirers that hail from more favorable tax jurisdictions are able to create value simply by restructuring the affairs of the U.S. target companies to improve their tax profile." ${ }^{\prime 1}$ In the subset of foreign acquisitions where that greater value in the hands of a foreign firm is driven by increased opportunities for tax minimization, the resulting increase in foreign direct investment (and the resulting apparent "increase" in employment of Americans by U.S. affiliates of foreign firms and "decrease" in employment of Americans by domestic firms) is simply not in the national interest of the United States. Indeed, a tax system that artificially encourages foreign ownership of originally U.S. assets that would otherwise be owned by more productive U.S.

\footnotetext{
17 Bureau of ECON. ANAlysis, U.S. DeP'T OF COMMERCE, 17-35 BEA EXPENDITURES By Foreign DiRECT INVESTORS FOR NEW INVESTMENT IN THE UNITED STATES, 2014-2016, (2017) https://www.bea.gov/newsreleases/international/fdi/fdinewsrelease.htm.

18 Impact of the U.S. Tax Code on the Market for Corporate Control and Jobs, Permanent Subcomm. on Investigations, Senate Comm. on Homeland Security and Governmental Affrs., $114^{\text {th }}$ Cong. 2 (2015) (Majority Staff Report).
} 
owners is not just disadvantageous for the United States - it will tend to reduce global wellbeing. ${ }^{19}$

\section{Favoring Foreign MNCs over U.S. MNCs Reduces Economic Opportunity}

While both U.S. MNCs and foreign MNCs support high-value jobs in the United States, U.S. MNCs tend to be more dedicated to U.S. employment. In those cases where a business asset would otherwise be equally productive under U.S. or foreign ownership, one should on average expect that business asset in the hands of a MNC with U.S. tax residence to produce more skilled jobs for Americans than the same business asset owned by a foreign MNC. For more than a generation, the labor market here and globally has been characterized by an increase in returns to skilled vs. semi-skilled and unskilled labor. Since there is no reason to believe this trend is likely to change, fewer skilled jobs located in the U.S. would reduce the opportunity set for younger Americans, and lead to both greater inequality and lower standards of living for our children and grandchildren.

We may one day reach a point where multinational firms are totally "decentered," such that national residence will have no effect on country of employment. But that day has not arrived. Moreover, there is no reason to believe it is likely to arrive during the probable lifetime of this round of corporate tax reform. Thus, in order to maximize opportunity for our kids, we must level the playing field and change the tax code to stop discouraging the formation, asset ownership by, and continued existence of U.S. MNCs relative to foreign MNCs. To do so, the U.S. must remove the incentives for tax-motivated foreign takeovers of U.S. firms, corporate "inversions," and initial foreign tax domiciliation to avoid U.S. tax-resident status. To achieve that result it is necessary - but not sufficient-for the United States to lower its corporate rate and move to a territorial system. The United States also has to deal with the problem of undertaxation of foreign-owned U.S. corporations. ${ }^{20}$

\section{Our Unlevel Playing Field}

Most debates on international tax reform have thus far focused on income earned abroad by U.S. MNCs. However, arguably the greatest structural tax disadvantage of being a U.S.-resident corporation relates to the taxation of income earned in the United States. U.S. MNCs are much more constrained than foreign MNCs from stripping income out of the U.S. tax base. A foreign MNC can reduce the amount it owes to the U.S. government through deductible interest and royalty payments from its U.S. affiliates to its foreign affiliates, as well as by charging its U.S. affiliates prices for goods or services that include the value of foreign-owned intangibles in highpriced products for resale in the United States. ${ }^{21}$ A U.S. MNC cannot use deductible related party

\footnotetext{
${ }^{19}$ As Mihir Desai and James Hines have persuasively shown, "if the productivity of capital depends on the identities of its owners (and there is considerable reason to think that it does), then the efficient allocation of capital is one that maximizes output given the stocks of capital in each country. It follows that tax systems promote efficiency if they encourage the most productive ownership of assets within the set of feasible investors." Mihir Desai \& James R. Hines, Jr., Evaluating International Tax Reform, 56 NAT'L TAX J. 487, 494 (2003).

${ }^{20}$ A recent article by Julie Roin addresses the technical questions associated with this problem in depth, and I recommend it to the Committee. Roin, supra note 5.

${ }^{21}$ Other deductible payment streams, including rents, premiums, and management service fees made from foreign controlled domestic affiliates to foreign affiliates can also be used by foreign MNCs to strip the U.S. tax base.
} 
interest and royalty payments in the same way. U.S. MNCs are also somewhat more constrained in reducing their U.S. tax liability by embedding foreign-owned intellectual property in products sold into the United States.

The relative tax advantages that benefit foreign MNCs are in large measure the result of specific structural features of our tax law. Most notably, royalty and interest income earned by foreign affiliates of U.S. MNCs is generally subject to inclusion on a current basis as part of "subpart F." The subpart F regime applies only to U.S. MNCs. It imposes U.S. tax on certain items of foreign income earned by the foreign affiliates of U.S. MNCs. Planning techniques exist to limit the impact of these rules with respect to income generated by foreign affiliates in sales made outside the United States, but these techniques generally do not work for payments made by U.S. affiliates of a U.S. MNC to its foreign affiliates. For example, the benefits of section 954(c)(6) which can limit the impact of subpart $\mathrm{F}$ with respect to payments made between foreign affiliates - are not available for payments made by a U.S. affiliate of a U.S. MNC to a foreign affiliate of a U.S. MNC. As a result, U.S. MNCs can use section 954(c)(6) to reduce the tax burden on their foreign earnings but not on their domestic earnings.

In contrast, foreign-resident MNCs can strip the U.S. tax base with very few limitations by structuring related party interest and royalty payments with their U.S. affiliates. They do not need to rely on subpart $\mathrm{F}$ planning techniques because subpart $\mathrm{F}$ does not apply to them. By statute, interest and royalty payments these foreign MNCs make to their foreign affiliates are theoretically subject to U.S. withholding taxes, but such taxes almost never apply under our tax treaties, which generally reduce these withholding taxes to zero. ${ }^{22}$

Another way to see the senselessness of focusing our international tax policy debate primarily on residence country taxation of U.S. MNCs is to consider the so-called "roundtripping" debate. Roundtripping is used in the international tax debate as a pejorative term meant to characterize a strategy employed by a limited group of U.S. MNCs to reduce their U.S. tax liability on U.S. sales by making deductible payments to foreign affiliates owning the U.S. rights to intellectual property incorporated into goods and services sold into the United States. "Roundtripping" by a subset of U.S. MNCs has been treated as a separate question deserving of special scrutiny in the international tax debate for at least the last six years. For example, concerns regarding roundtripping motivated the decision to limit the reduced U.S. tax rate on putatively foreign intangible income provided in former House Ways and Means Chairman Camp's tax reform proposal to income derived from foreign customers. ${ }^{23}$

However, the same basic planning technique used by "roundtrippers"- owning abroad the U.S. rights to intellectual property associated with the sale of goods and services into the United States - is also routinely used by foreign MNCs. Yet when undertaken by foreign MNCs this same planning technique has received almost no attention, let alone criticism. The lack of attention is despite evidence showing that European MNCs (for example) very

\footnotetext{
2226 U.S.C. $\$ 871$ (2012); U.S. Model Income Tax Convention Art. 11-12 (Treas. Dep’t 2006); U.S. Model Income Tax Convention Art. 11-12 (Treas. Dep't 2016).

${ }^{23}$ See H.R. 1, 113th Cong. § 4211(2nd. Sess. 2014).
} 
disproportionately hold their intellectual property in low- or no-tax jurisdictions. ${ }^{24}$ Given the malleability of corporate residence, as well as the evidence that in general U.S. MNCs tend to produce more high-quality jobs in the U.S. than foreign MNCs, why would the Congress attack a tax planning technique when undertaken by U.S. MNCs, but leave it untouched when employed by foreign MNCs?

Another perverse fact is that foreign MNCs can manufacture in the United States and still strip the U.S. tax base, whereas U.S. MNCs cannot. Under subpart F, a foreign affiliate of a U.S. multinational is able to earn IP income from embedded intangibles on both foreign and domestic sales without being subject to current taxation in the United States only if the foreign affiliate conducts the related manufacturing outside the United States. Thus, U.S. law in effect discourages U.S. MNCs from manufacturing in the United States. ${ }^{25}$

Given the fungibility of tax residence for business units (which can be acquired), new businesses (which can incorporate initially abroad), and multinationals as a whole (which are now routinely acquired by foreign firms), differentiating tax burdens based on U.S. tax residence or foreign tax residence is simply untenable. Yet our law is heavily based on an antiquated residence principle, and penalizes U.S. tax residence relative to foreign tax residence. This legal regime may have been appropriate when it came into being more than half a century ago, when cross-border mergers and acquisitions were rare and, when cross-border acquisitions did happen, they overwhelmingly involved U.S. MNC acquisitions of foreign firms. Now, however, this legal regime makes no sense.

\section{$\underline{\text { The Global Context }}$}

The U.S. debate regarding corporate tax reform is happening in a broader international tax context: the international tax environment around the world is becoming both less stable and less favorable to American business. The Base Erosion and Profit Shifting (BEPS) project at the OECD was justified as an attempt to prevent the old framework for international taxation from falling apart and being replaced by unilateral actions, double taxation of cross-border business, and what the OECD termed "global tax chaos." 26 Unfortunately, the post-BEPS environment already shows signs of becoming characterized by much of the global tax chaos the BEPS project was supposed to prevent. In particular, countries around the world are moving away from residence country taxation and towards source country taxation in a variety of often uncoordinated ways.

As a result of the BEPS project, transfer pricing norms globally were generally adjusted to, in the parlance of the OECD, "align income taxation with value creation." The key practical

\footnotetext{
24 See Matthias Dischinger \& Nadine Riedel, Corporate Taxes and the Location of Intangible Assets within Multinational Firms, 95 J. PUBLIC ECONOMIES 691 (2011) (examining a dataset of intangible holdings of the affiliates of EU-headquartered firms and finding "a robust inverse relation between the subsidiary's corporate tax rate relative to other group affiliates and its intangible asset holdings").

25 See Paul Oosterhuis \& Moshe Spinowitz, Presentation at the Brookings Institute/Urban Institute Tax Policy Center/ITPF Conference on Tax Policy and U.S. Manufacturing in a Global Economy: Tax Incentives to Conduct Offshore Manufacturing under Current Law (Mar. 15, 2013).

${ }^{26} 11$ Organisation for Economic Co-Operation and Development [OECD], Action Plan on Base Erosion and Profit Shifting, https://www.oecd.org/ctp/BEPSActionPlan.pdf.
} 
consequence of this agreement is to require MNCs to move high-skilled jobs (rather than merely shifting income) if they wish to benefit from the lower corporate tax rates available from America's competitor countries. Thus, a key outcome of the agreements reached in the BEPS project was to increase the negative consequences to American workers if the United States failed to lower our corporate tax rate and adopt a territorial system.

Since the BEPS project ended, countries as diverse as Australia, Chile, France, Germany, India, Israel, Italy, Japan, Mexico, New Zealand, Poland, Spain, and the United Kingdom have taken additional unilateral legislative or administrative actions. These unilateral actions are not limited by or consistent with the BEPS agreements and are designed to increase levels of inbound corporate income taxation. Moreover, a number of these actions have been designed so that, as a practical matter, they are targeted to primarily hit U.S. MNCs.

For example, in the last few years the European Commission invented a new "state aid" theory to target U.S. MNCs. ${ }^{27}$ And last month the European Commission went further and considered a joint Franco-German-Italian-Spanish proposal to impose a so-called "equalization levy" on U.S. tech companies based on their gross turnover in EU countries, which is supposed to make up for their paying insufficient corporate income tax. At the September European Union Economic and Financial Affairs Council ("ECOFIN") meeting, finance ministers expressed unanimous support for some form of action to tax "enterprises that use digital technology." The ministers agreed to move forward swiftly and to reach a common understanding at the ECOFIN in December. Moreover, the current presidency of the ECOFIN asserted that "[i]f we can agree on the approach inside the European Union, then we can also affect the global rules in a way that is favourable to us." ${ }^{28}$ Less than a week later the European Commission followed up with a statement that "unilateral initiatives in the EU and internationally will continue to develop," and made proposals for various gross-basis taxes on revenues from digital business only. ${ }^{29}$ As a practical matter, this proposed tax is quite obviously targeted at U.S. companies.

The strategic questions implied by the unsettled state of international tax affairs should feature as an important consideration in the policy discussions surrounding U.S. international tax reform. Unfortunately, to date many analysts have maintained the historic American tendency to treat the diplomatic and competitive processes entailed in multilateral discussion of international tax rules as a second-order matter. In effect, some analysts pretend that if the U.S. takes decisive action the rest of the world will just follow, or behave in ways that will not fundamentally alter the policy consequence of U.S. policy.

\footnotetext{
27 For more on this issue see my 2016 testimony before the House Ways and Means Committee. Global Tax Environment in 2016 and Implications for International Tax Reform: Hearing Before the Comm. on Ways and Means Comm., 114th Cong. 2 (2016) (Statement of Itai Grinberg).

${ }^{28}$ European Commission Press Release 16/09/2017, Economic and Financial Affairs Council, EU finance ministers agreed to develop new digital taxation rules (Sept. 16, 2017), https://www.eu2017.ee/news/press-releases/eufinance-ministers-agreed-develop-new-digital-taxation-rules.

${ }^{29}$ Communication from the Commission to the European Parliament and the Council, A Fair and Efficient Tax System in the European Union for the Digital Single Market, COM (2017) 547 Final (Sept. 21, 2017).
} 
Despite being the world's largest economy, in the international tax diplomatic space the United States has been losing for a number of years. We have failed to successfully defend our national interests, and have been repeatedly out-negotiated. One underlying cause of these failures has been our inability to enact international tax reform that defines a corporate tax base that we can successfully defend.

Historically the multilateral international tax architecture was heavily focused on residence country taxation. The international tax architecture around the world is shifting towards greater source-based taxation, but that transition is liable to be long and messy.

If we continue to insist on the idea of worldwide residence country taxation of U.S. MNCs, we will simply make U.S. MNCs uncompetitive outliers subject to foreign revenue grabs. Moreover, with respect to inbound taxation, it is important to understand that we have no international status quo, and we are likely taking the first steps in a multistage, multi-country game.

As a result, the inbound policy result the U.S. reaches in tax reform in this Congress will almost certainly be revisited repeatedly, spurred on by both unilateral actions by other countries and multinational negotiations. This time the inbound piece of international tax reform will not be a once in a generation event. Therefore, when addressing inbound corporate tax reform in this Congress, policymakers should seek to give the United States leverage. It is important to put the United States in a good position to bargain internationally about a future set of broadly accepted rules that will most likely be agreed to multilaterally at a later date.

\section{The U.S. Response Must be Administrable Unilaterally}

In crafting our inbound taxation policy we should keep in mind whether any given regime requires multilateral cooperation to be effective. For example, proposals that are only administrable with significant new information sharing with foreign sovereigns require international agreement. In the short-term such agreement seems unlikely.

The difficult international tax diplomatic environment means that for the time being it may be more important that U.S. legal changes be administrable by the U.S. alone, rather than being as intellectually or technically robust as possible. At the same time, changes to our law should not involve technical innovations that we would strenuously oppose if used abroad. For example, it would be difficult for the United States to maintain that virtual permanent establishments are inappropriate abroad and simultaneously move forward with a deemed permanent establishment arrangement as part of income tax reform at home.

To ensure that our policy reflects the principle that we are working to level the playing field, the primary inbound measures the U.S. adopts should affect all industries and treat domestic and foreign firms equivalently in theory and practice. That must be one of the principles for eventual international agreement, and-unlike Europe - the United States' Wilsonian tradition stands for being a beacon of principle in international relations. Treating U.S. and foreign MNCs equivalently also helps preserve international economic law rules that generally prohibit discrimination against foreigners on the basis of national origin. 
Nevertheless, within any inbound piece of tax reform, we also should consider including a punitive measure to discourage the imposition of particularly economically destructive taxes. For example, the gross basis turnover taxes on digital business proposed by the European Commission represent a mercantilist effort to target U.S. firms. The European Commission is proposing to revive a form of particularly inefficient taxation that was largely abandoned long ago. If actions like these are being proposed by our trading partners, we need U.S. legislation to make clear that attacks targeted at U.S. MNCs would have meaningful consequences. In that circumstance the balance of economic power would make it possible to reach a principled global settlement.

In sum, despite the unsettled global environment, the United States needs to act on reforming its inbound rules. What we need for the time being on inbound is a pragmatic, administrable policy that helps level the playing field between U.S. and foreign MNCs. The policy should be based on a defensible principle - for instance an inbound corporate minimum tax. ${ }^{30}$

\section{A Minimum Tax Targeted at U.S. MNCs Should Not be the Focus of the Anti-Base Erosion $\underline{\text { Regime }}$}

One anti-base erosion proposal that has received prominent consideration in recent congresses is some form of minimum tax built onto the infrastructure of subpart $\mathrm{F}$ and used to reach intangible income. Unlike an inbound corporate minimum tax, such proposals target U.S. MNCs and only U.S. MNCs. In effect a minimum tax imposed on only U.S. MNCs is just a worldwide system with a lower rate for foreign source income than domestic source income. No other country on Earth has such a system. To the extent we impose such a tax at a significant rate we will continue to discourage U.S. tax residence and encourage foreign tax residence for all cross-border business.

Subpart F-based minimum tax proposals target U.S. MNCs to pay more tax to the U.S. just as foreign sovereigns are targeting these same MNCs to pay more source country tax. However, because residence taxation is a residual obligation, the end result of enacting a high subpart $\mathrm{F}$ based minimum tax would not likely be that U.S. MNCs would pay more tax to the United States.

Rather, because foreign taxes are generally creditable against U.S. tax liability, in a minimum tax system U.S. MNCs will tend to be indifferent to increased foreign taxes relative to MNCs resident in territorial countries. Why take the risk of planning to avoid a foreign tax, when under a minimum tax combined with a foreign tax credit, the ultimate cost of foreign source country income taxes (up to the level of the minimum tax) will generally be borne by the U.S. fisc rather than the company? Moreover, as other countries increase their source-based taxes, a residencebased minimum tax coupled with a foreign tax credit positively encourages other countries to

\footnotetext{
${ }^{30}$ Arguing that some part of income in part attributable to intellectual property should be taxed by the source state is not a new idea. See, e.g., Lawrence Lokken, The Sources of Income from International Uses and Dispositions of Intellectual Property, 36 TAX. L. REV. 233, 243 (1981). Some version of this point arguably dates all the way back to the work of the International Chamber of Commerce in the 1920s. See e.g., Bret Wells \& Cym Lowell, Income Tax Treaty Policy in the 21st Century: Residence vs. Source, 5 COLUM. J. TAX L. 1 (2014).
} 
specifically target U.S. MNCs with their own source-based taxes. Thus, the most likely consequence of enacting a significant minimum tax that applies only to U.S. MNCs is that businesspeople and tax professionals will conclude that the best way to protect a business asset from attack by both the U.S. and foreign tax authorities is to take it out of the U.S. tax net, and make that asset tax resident somewhere else. The medium-term consequence of such decisions would be fewer jobs for U.S. workers.

The recently released "Unified Framework for Fixing Our Broken Tax Code" makes two key commitments to protect the U.S. tax base. The framework suggests the Committee will "incorporate rules to level the playing field between U.S.-headquartered parent companies and foreign-headquartered parent companies." 31 It also states that "the framework includes rules to protect the U.S. tax base by taxing at a reduced rate and on a global basis the foreign profits of U.S. multinational corporations." To the extent this means that the Committee may include a subpart F-based minimum tax proposal as part of tax reform, it should set the rate as low as possible, provide for foreign tax credit haircuts, and pair that idea with an inbound corporate minimum tax. In this way a subpart F-based minimum tax proposal could incentivize U.S. multinationals to risk tax disputes with foreign sovereigns rather than decreasing tax payments to the U.S., while limiting the degree to which a subpart F-based minimum tax would make the playing field less level. ${ }^{32}$ Adopting a form of corporate integration that passes the benefit of only U.S. taxes paid by U.S. MNCs through to taxable U.S. shareholders could also help ameliorate the foreign tax payment incentive that could be created by even a low-rate subpart F-based minimum tax..$^{33}$

The most effective anti-base erosion proposal, however, would be to find a way to lower the corporate tax rate even further, and not just meet, but beat our global competitors. When corporate income tax rates are significantly lower than those of competitor countries, other antibase erosion measures become both less contentious and less important. The most plausible approach to accomplish such an achievement would be to adopt a value-added tax and use the revenue to sharply lower both corporate and individual income tax rates. A number of highly esteemed witnesses appearing before the Committee have made this point, ${ }^{34}$ and Senator Cardin has introduced a bill with some of these admirable features. While adding another tax base is likely outside the scope of the current tax reform effort-as a destination-based tax, the valueadded tax naturally taxes an immobile factor and therefore is much less susceptible to base erosion. Moreover, the revenue generated by a value-added tax could be used to cut income taxes sharply across the board without raising concerns regarding fiscal sustainability. Finally, as a tax

31 Unified Framework for Fixing Our Broken Tax Code (Sept. 27, 2017), https://www.treasury.gov/presscenter/press-releases/Documents/Tax-Framework.pdf.

${ }^{32}$ See Daniel Shaviro, The Case Against Foreign Tax Credits (N.Y.U L. \& Econ. Working Papers No. 208, March 2010).

${ }^{33}$ For further discussion see Integrating the Corporate and Individual Tax Systems: The Dividends Paid Deduction Considered Before the Sen. Fin. Comm., 114th Cong. 2 (2016) (Statement of Michael J. Graetz, Wilbur H. Friedman Professor of Tax Law and Columbia Alumni Professor of Tax Law at Columbia University), https://www.finance.senate.gov/imo/media/doc/16MAY2016Graetz.pdf; Bret Wells, International Tax Reform by Means of Corporate Integration, 20 Fla. Tax Rev. 70 (2016).

${ }^{34}$ See, e.g., Statement of Michael J. Graetz, id, Comprehensive Tax Reform: Prospects and Challenges: Hearing Before the Senate Comm. on Finance, 115th Cong. (2017) (Statement of Pamela F. Olson), https://www.finance.senate.gov/imo/media/doc/Pamela\%20Olson\%20Testimony.pdf. 
on consumption, the VAT is just more efficient and pro-growth than business income taxes. It also could be a fairer way to address the intergenerational consequences of our unfunded entitlement liabilities and help ensure greater prosperity and opportunity for our children.

\section{Conclusion}

As both Chairman Hatch and Ranking Member Wyden have pointed out in the past, the United States corporate and international tax rules are an anticompetitive mess. ${ }^{35}$

Among taxes currently in use by developed economies, the corporate income tax is (as the OECD has pointed out repeatedly $)^{36}$ the tax that is the most harmful to economic growth. Unsurprisingly, then, governments around the world have come to view reducing corporate income tax rates and moving to a territorial system as tools to attract investment and jobs.

Lowering the corporate income tax rate and moving to a territorial system are important to maintain U.S. prosperity and improve growth prospects for our economy. The U.S. cannot stand apart from corporate tax competition in a globalized economy and is falling further behind each year.

To ensure that corporate income tax reform maximizes opportunity for well-paid employment for as many of our children and grandchildren as possible, the United States must also level the playing field between U.S. and foreign-headquartered MNCs. Leveling the playing field requires addressing the relative tax advantages available to foreign-owned U.S. corporations that represent one of the most senseless aspects of our current corporate tax code.

\footnotetext{
35 At the Committee's 2014 international tax hearing, while Senator Wyden described our system as anticompetitive, Pascal St. Amans - a French socialist who testified in his role as Director of the OECD's Centre for Tax Policy and Administration-went further and chose to describe the U.S. corporate tax system as "diseased." U.S. Tax Code: Love It, Leave It, or Reform It: Hearing Before the Sen. Comm. on Finance, 113th Cong. 2 (2014)

${ }^{36}$ See Organisation for Economic Co-Operation and Development [OECD], Tax Policy Reform and Economic Growth, OECD Tax Policy Studies, No. 20 (Nov. 3, 2010); see also, Asa Johnansson, Organisation for Economic Co-Operation and Development [OECD], Public Finance, Economic Growth and Inequality: A Survey of the Evidence, ECO/WKP(2016)70 (Nov. 22, 2016); Asa Johansson, Organisation for Economic Co-Operation and Development [OECD], Tax and Economic Growth, ECO/WKP(2008)28 (Jul. 11, 2008).
} 